\title{
Review Article \\ Impacts of Two Types of El Niño and La Niña Events on Typhoon Activity
}

\author{
Po-Chun Hsu, Chung-Ru Ho, Shin-Jye Liang, and Nan-Jung Kuo \\ Department of Marine Environmental Informatics, National Taiwan Ocean University, Keelung 20224, Taiwan \\ Correspondence should be addressed to Chung-Ru Ho; b0211@mail.ntou.edu.tw
}

Received 6 September 2013; Revised 8 December 2013; Accepted 8 December 2013

Academic Editor: Yuriy Kuleshov

Copyright (C) 2013 Po-Chun Hsu et al. This is an open access article distributed under the Creative Commons Attribution License, which permits unrestricted use, distribution, and reproduction in any medium, provided the original work is properly cited.

\begin{abstract}
The HadISST (Hadley Centre Sea Ice and Sea Surface Temperature) dataset is used to define the years of El Niño, El Niño Modoki, and La Niña events and to find out the impacts of these events on typhoon activity. The results show that the formation positions of typhoon are farther eastward moving in El Niño years than in La Niña years and much further eastward in El Niño Modoki years. The lifetime and the distance of movement are longer, and the intensity of typhoons is stronger in El Niño and in El Niño Modoki years than in La Niña years. The Accumulated Cyclone Energy of typhoon is highly correlated with the Oceanic Niño Index with a correlation coefficient of 0.79 . We also find that the typhoons anomalously decrease during El Niño years but increase during El Niño Modoki years. Besides, there are two types of El Niño Modoki, I and II. The intensity of typhoon in El Niño Modoki I years is stronger than in El Niño Modoki II years. Furthermore, the centroid position of the Western Pacific Warm Pool is strongly related to the area of typhoon formation with a correlation coefficient of 0.95 .
\end{abstract}

\section{Introduction}

Recent studies have found that there are two types of El Niño in the tropical Pacific, namely: Eastern-Pacific El Niño (EPEl Niño) and Central-Pacific El Niño (CP-El Niño) [1, 2]. The EP-El Niño is the canonical El Niño; a band of anomalous warm ocean water occurs in the eastern tropical Pacific. The CP-El Niño is also called El Niño Modoki, which is the band of anomalous warm ocean water occurring in the central equatorial Pacific. In this study, to avoid the confusion of the nomenclature used, hareafter the Eastern-Pacific El Niño is named as El Niño and the Central-Pacific El Niño is named as El Niño Modoki. The occurrences of anomalous warm water at different regions may cause different changes in air pressure, sea surface height, precipitation, and wind field [37]. Yu and Kao [8] and Kao and Yu [9] pointed out that the generation mechanism of the El Niño tied to thermocline variations but the El Niño Modoki may be affected significantly by atmospheric forcing than by basin-wide thermocline variations. Changes of oceanic environment in El Niño and La Niña events may alter the formation and intensity of a typhoon because warmer oceanic environment is more suitable for its formation and intensity increase [10-16]. Besides the influence of El Niño and La Niña events, Wang et al. [17] showed that different impacts of El Niño and El Niño Modoki events may also change the formation locations, durations, and intensities of tropical cyclones. They indicated that tropical cyclone tends to be more intense in El Niño years than in El Niño Modoki years. Furthermore, according to the rainfall anomaly patterns in southern China, C. Wang and X. Wang [18] indicated that there are two groups of El Niño Modoki, I and II. Different groups are associated with different atmospheric circulation patterns in the western North Pacific and therefore affect the typhoon tracks in the western North Pacific. However, the typhoon tracks, the effects of other characteristics of typhoons, such as the formation position, lifetime, and range of movement, and moving speed are still not clear. To statistically investigate the characteristics of typhoons in these abnormal events and their relationships with changes of the western Pacific warm pool (WPWP), we conduct this study using the Hadley Centre Sea Ice and Sea Surface Temperature (HadISST) dataset and the typhoon datasets from the Japan Meteorological Agency (JMA) and the Joint Typhoon Warning Center (JTWC). 


\section{Data and Methods}

The Oceanic Niño Index (ONI) provided by the Climate Prediction Center in the National Oceanic and Atmospheric Administration (NOAA) is used to define El Niño and La Niña events. The anomalous ONI value of five consecutive months at or above +0.5 is defined as an El Niño event and at or below -0.5 is defined as a La Niña event. The El Niño Modoki Index (EMI) and the second mode of the empirical orthogonal functions (EOF) resulting from tropical Pacific sea surface temperature anomaly (SSTA) data are used to identify the El Niño Modoki pattern. The SSTA data is derived from HadISST, which is a monthly dataset with a spatial resolution of $1^{\circ} \times 1^{\circ}$. The El Niño Modoki Index (EMI) is defined as

$$
\mathrm{EMI}=[\mathrm{SSTA}]_{\mathrm{A}}-0.5 \times[\mathrm{SSTA}]_{\mathrm{B}}-0.5 \times[\mathrm{SSTA}]_{\mathrm{C}},
$$

where the brackets with a subscript represent the areaaveraged SSTA over the central Pacific region A $\left(10^{\circ} \mathrm{S}-10^{\circ} \mathrm{N}\right.$, $\left.165^{\circ} \mathrm{E}-140^{\circ} \mathrm{W}\right)$, the eastern Pacific region $\mathrm{B}\left(15^{\circ} \mathrm{S}-5^{\circ} \mathrm{N}\right.$, $\left.70^{\circ} \mathrm{W}-110^{\circ} \mathrm{W}\right)$, and the western Pacific region $\mathrm{C}\left(10^{\circ} \mathrm{S}-20^{\circ} \mathrm{N}\right.$, $\left.125^{\circ} \mathrm{E}-145^{\circ} \mathrm{E}\right)$, respectively.

The area and sea surface temperature (SST) of WPWP might be affected by El Niño, El Niño Modoki, and La Niña events. To find out the changes of WPWP with typhoon characteristics during these events, the study area is limited to $40.5^{\circ} \mathrm{N}-30.5^{\circ} \mathrm{S}$ and $120.5^{\circ} \mathrm{E}-119.5^{\circ} \mathrm{W}$. The area within the $28^{\circ} \mathrm{C}$ isotherm of SST is defined as the area of WPWP. It can be calculated by [19]

$$
A=\sum_{i=1}^{n} \cos \phi_{i} \times(111.319 \mathrm{~km})^{2},
$$

where $A$ is the area of WPWP, $\phi_{i}$ is the latitude of the pixel within the WPWP, $(111.319 \mathrm{~km})^{2}$ is the area of each $1^{\circ}$ grid, and $n$ is the total number of pixels in the WPWP. The centroid of the WPWP is then defined as [20]

$$
\bar{x}=\sum_{i=1}^{n} \frac{x_{i}}{n}, \quad \bar{y}=\sum_{i=1}^{n} \frac{y_{i}}{n},
$$

where $x_{i}$ is the zonal position of a pixel and $y_{i}$ is the meridional position of a pixel within the WPWP.

Typhoon data is obtained from JMA and JTWC. The contents of both datasets include longitude, latitude, lifetime, minimum pressure and maximum wind, length of movement, average moving speed, and range of movement of a typhoon. Typhoon grading intensity standards with reference to the JMA are according to the definition of National Hurricane Center. The Accumulated Cyclone Energy (ACE) formula is used to identify the intensity of a typhoon and is defined as [21]:

$$
\mathrm{ACE}=10^{-4} \sum_{i=1}^{N} \sum_{j=1}^{T} V_{i j}^{2}
$$

where $N$ is the number of typhoon in a year of each event, $T$ is the total number of 6-hourly estimate in a typhoon, and $V$ is the 6-hourly maximum sustained wind speed in knot (kt). The ACE index is widely used by NOAA and recent studies [22-26]. It is a wind energy index, a combination of the number of typhoon, the existence time of a typhoon, and the intensing of a typhoon at each observing time.

\section{Results}

3.1. El Niño, El Niño Modoki, and La Niña. The years of El Niño and La Niña in the period of 1950-2012 are defined by ONI. We have identified $19 \mathrm{El}$ Niño events and $21 \mathrm{La}$ Niña events during the data span. In the El Niño years, warm water moves from west to east with Kelvin waves in the tropical Pacific and replaces the cold surface water of the Humboldt Current. Extensive Pacific warming and the reduction in easterly trade winds limit upwelling of cold water in the equatorial eastern Pacific. The La Niña year is the opposite of the El Niño year; SST across the eastern and central equatorial Pacific is lower than normal. The El Niño Modoki has its warm SST anomaly in the $10^{\circ} \mathrm{S} \sim 10^{\circ} \mathrm{N}$, $165^{\circ} \mathrm{E} \sim 140^{\circ} \mathrm{W}$. We applied the empirical orthogonal function (EOF) analysis to the tropical Pacific SST to identify modes of variability relevant to the El Niño Modoki pattern and identified El Niño Modoki events by EMI and the EOF results. Four patterns of SSTA in the equatorial Pacific are shown in Figure 1. From 1977 to 2012, the El Niño Modoki events occurred in eight years. The EOF1 pattern counts about $50 \%$ of the tropical Pacific SST variability. Comparing the time series of its principal component with the normalized ONI, the correlation coefficient is up to 0.94 . The EOF2 explains $12 \%$ of the tropical Pacific SST variability and shows the El Niño Modoki pattern in the equatorial Pacific. The warmest SST occurs in the central Pacific, flanked by colder water to the west and east. The correlation coefficient between EMI and the second principle component is 0.84 .

Previous study [18] shows that there are two groups of El Niño Modoki. Here we use the definitions of ONI and EMI and find the two types of El Niño Modoki, I and II. For El Niño Modoki I, it is the year of El Niño Modoki defined by EMI and is also the year of an El Niño year defined by ONI. For El Niño Modoki II, it is the year of El Niño Modoki defined by EMI but is a normal year defined by ONI. Using this definition, the years of El Niño, El Niño Modoki I, El Niño Modoki II, and La Niña events are listed in Table 1.

3.2. Activity of Western Pacific Typhoon. The best track data of typhoon provided by JMA are used in this study. There are 1594 typhoons found from 1951 to 2011, 492 in El Niño years, 512 in La Niña years, and 590 in normal years. The average of formation position of typhoons is at $15.2^{\circ} \mathrm{N}, 140.6^{\circ} \mathrm{E}$ in El Niño years, at $17.2^{\circ} \mathrm{N}, 135^{\circ} \mathrm{E}$ in La Niña years, and at $16.2^{\circ} \mathrm{N}, 136.5^{\circ} \mathrm{E}$ in normal years. Comparing El Niño and El Niño Modoki years in the period of 1977 to 2011, typhoon began its extended lifecycle at $14.8^{\circ} \mathrm{N}, 140.2^{\circ} \mathrm{E}$ in El Niño years, at $15.6^{\circ} \mathrm{N}, 141.4^{\circ} \mathrm{E}$ in El Niño Modoki I years, and at $15.4^{\circ} \mathrm{N}, 141.7^{\circ} \mathrm{E}$ in El Niño Modoki II years (Figure 2).

Statistical results of formation position, ACE, number, maximum wind speed, lifetime, distance of movement, minimum pressure, moving speed, and moving range of 


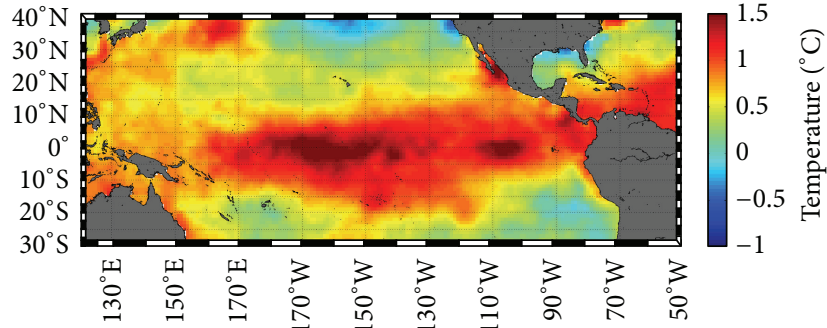

(a)



(c)

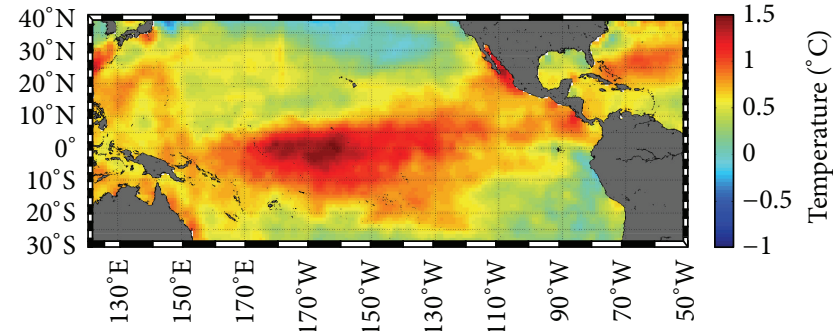

(b)

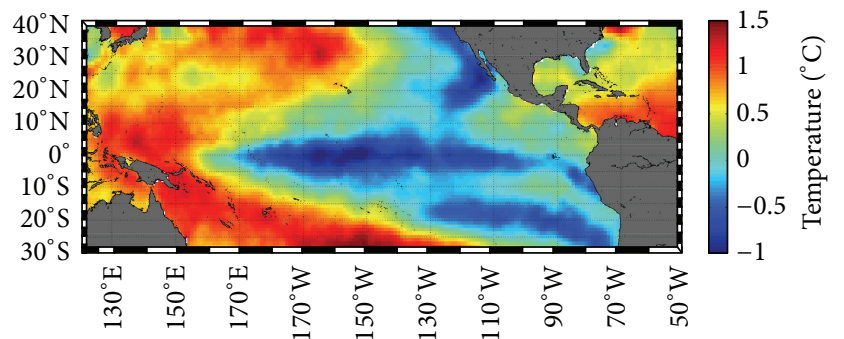

(d)

FIGURE 1: SST anomaly of (a) 2009-2010, (b) 2002-2003, (c) 1992-1993, and (d) 2010-2011 as examples for El Niño, El Niño Modoki I, El Niño Modoki II, and La Niña events, respectively.

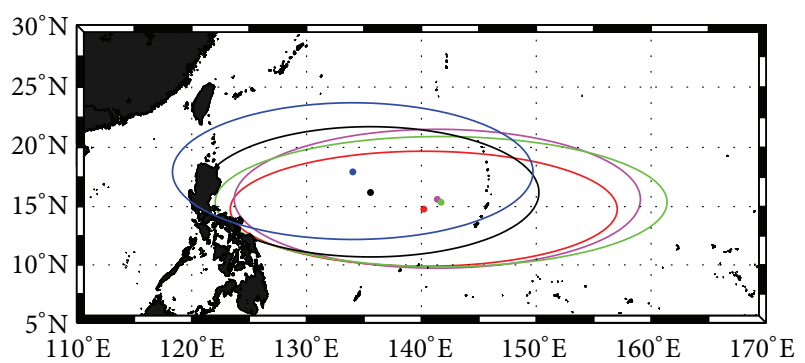

FIGURE 2: The average formation area of typhoon in El Niño years (Red), El Niño Modoki I years (Magenta), El Niño Modoki II years (Green), La Niña years (Blue), and normal years (Black). The semimajor and semiminor axes of an ellipse are the standard deviation of formation positions of typhoons in longitude and latitude, respectively.

typhoon are summarized in Table 2. The lifetime, distance of movement, and movement range of typhoon are larger in El Niño/El Niño Modoki years than those in La Niña years. However, the moving speed is less different between the two events. In the period of 1977 to 2011, the lifetime, distance of movement, and movement range of typhoon are larger in El Niño Modoki I than in El Niño Modoki II years, but the moving speed is almost the same. The average formation position of typhoons is moved further eastward in El Niño years than in La Niña years and much further eastward in El Niño Modoki years. We also make a statistical analysis of typhoon in the northwest Pacific during the period of 1951 to 2011 and find that the typhoon strength and movement in El Niño and La Niña years are similar to the time period 19772011. Comparing toearlier relevant works $[27,28]$, although the definition of El Niño and El Niño Modoki years in these
Table 1: The years of El Niño, El Niño Modoki I, El Niño Modoki II, and La Niña events from 1950 to 2012.

\begin{tabular}{ll}
\hline Event & Year (from July to June of next year) \\
\hline \multirow{2}{*}{ El Niño } & $1951-52,1957-58,1963-64,1965-66,1968-69$, \\
& $1969-70,1972-73,1976-77,1982-83,1987-88$, \\
& $1997-98,2006-07,2009-10$ \\
\hline \multirow{2}{*}{ El Niño Modoki I } & $1977-78,1986-87,1991-92,1994-95,2002-03$, \\
& $2004-05$ \\
\hline El Niño Modoki II & $1990-91,1992-93$ \\
\hline \multirow{2}{*}{ La Niña } & $1950-51,1954-57,1962-63,1964-65,1967-68$, \\
& $1970-72,1973-76,1984-85,1988-89,1995-96$, \\
& $1998-01,2007-08,2010-12$ \\
\hline
\end{tabular}

works is slightly different, the results all indicate that the typhoons anomalously decrease during El Niño years but increase during El Niño Modoki years.

We use ACE to measure overall activity of typhoon during a year. The calculation of average ACE (Unit: $10^{4} \mathrm{kt}^{2}$ ) shows 292.1 in El Niño years, 316.1 in El Niño Modoki I years, 306.6 in El Niño Modoki II years, 217.5 in normal years, and 160.9 in La Niña years. This result indicates that the longer distances of typhoon movement and the higher maximum wind speed of typhoon result in larger ACE value. This observation is consistent with the aforementioned statistical results. Figure 3 shows the mean ACE of a year in the five events. Figure 4 is a scatter plot of ACE and ONI with a coefficient of determination $\left(R^{2}\right)$ of 0.6 . This clarifies that the formation position and the intensity of typhoon are obviously affected by El Niño, El Niño Modoki, and La Niña events.

The definition of maximum wind speed of typhoons provided by JMA (10 min mean) is different from that of 


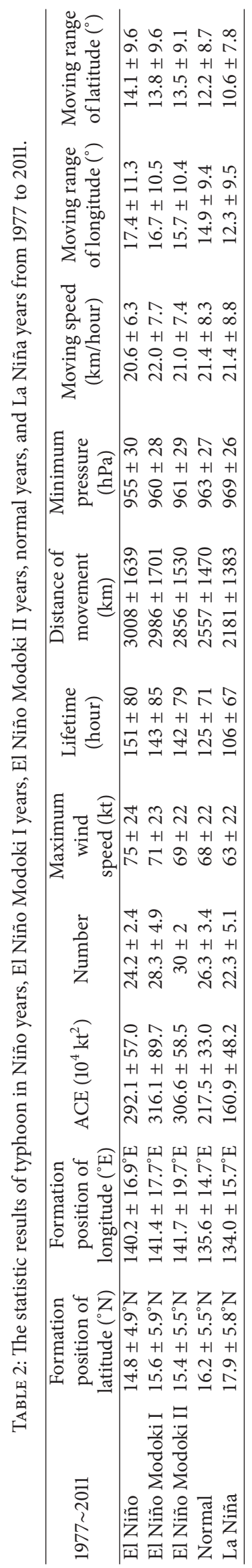


TABLE 3: Percentage of different typhoon categories of each event for JMA and JTWC from 1977 to 2011.

\begin{tabular}{lcccccc}
\hline Event/data & \multicolumn{2}{c}{ JMA } & \multicolumn{2}{c}{ JTWC } \\
& Tropical storm & Category 1+2 & Category 3+4+5 & Tropical storm & Category 1+2 & Category 3 + 4 + 5 \\
\hline El Niño & $33.9 \%$ & $38.0 \%$ & $28.1 \%$ & $25.8 \%$ & $28.3 \%$ & $45.8 \%$ \\
El Niño Modoki I & $41.8 \%$ & $44.1 \%$ & $14.1 \%$ & $32.7 \%$ & $29.6 \%$ & $37.7 \%$ \\
El Niño Modoki II & $41.7 \%$ & $45.0 \%$ & $13.3 \%$ & $25.9 \%$ & $39.7 \%$ & $34.5 \%$ \\
Normal & $44.5 \%$ & $44.5 \%$ & $11.0 \%$ & $35.4 \%$ & $33.3 \%$ & $31.2 \%$ \\
La Niña & $54.7 \%$ & $36.8 \%$ & $8.5 \%$ & $41.5 \%$ & $27.7 \%$ & $30.8 \%$ \\
\hline
\end{tabular}

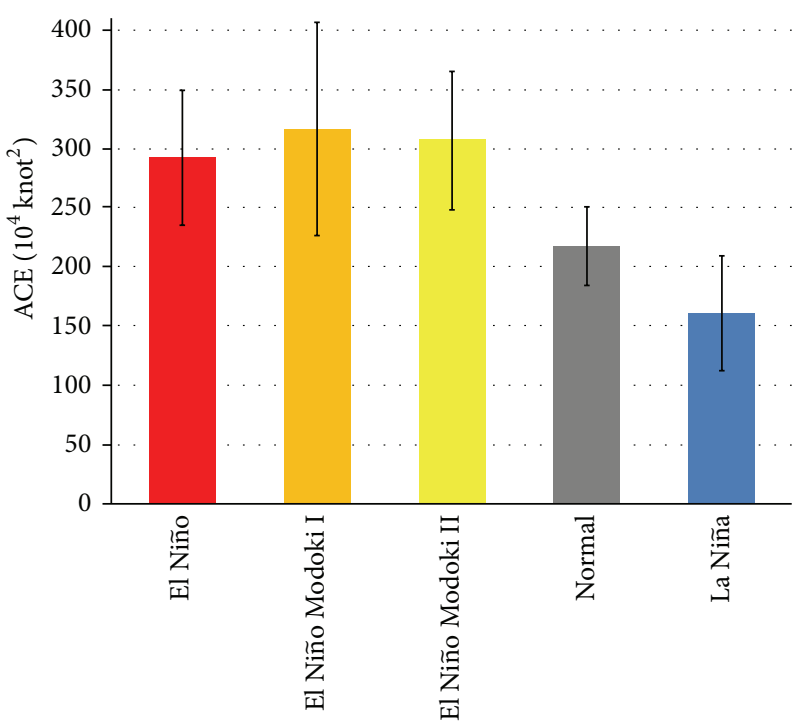

FIGURE 3: The mean of ACE of a year in the five events. The bar represents one standard deviation.

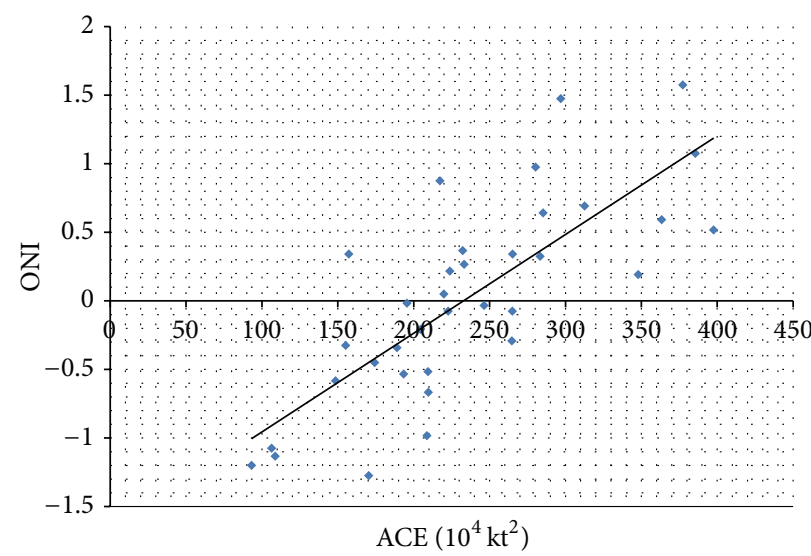

FIgURE 4: Relationship between ACE and ONI $\left(R^{2}=0.6\right)$.

JTWC (1 min mean). Therefore, the occurrence percentage of typhoon strength from both datasets may be different. A comparison of both datasets from 1977 to 2011 is shown in Table 3. Categories 1 to 5 are classified by the Saffir-Simpson hurricane wind scale. The rating is based on a hurricane's sustained wind speed. Tropical storm is defined as the maximum sustained winds between 34 and 64 knots, Category 1 is reserved for maximum sustained winds between 64 and 83 knots, Category 2 is $83-96$ knots, Category 3 is $96-113$ knots, Category 4 is $113-136$ knots, and Category 5 is exceeding 137 knots. Hurricanes reaching Category 3 and higher are considered major hurricanes because of their potential for significant loss of life and damage. Category 1 and 2 storms require preventive measures (http://www.nhc.noaa.gov/aboutsshws.php). Therefore, we divided the Category of Saffir-Simpson scale into two parts for analysis, Category $1+2$ and Category $3+4+5$. The results show that the occurrence frequency of Category $1+2$ and Category $3+4+5$ is reduced in La Niña years. For strong typhoon cases, that is, Category $3+4+5$, both datasets show 


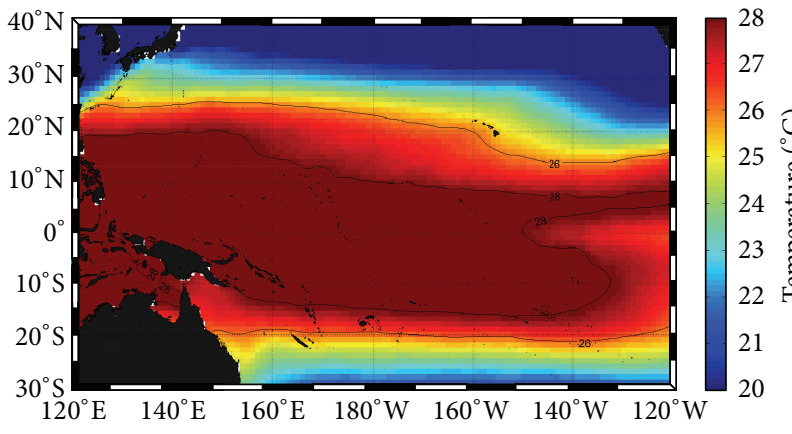

(a)

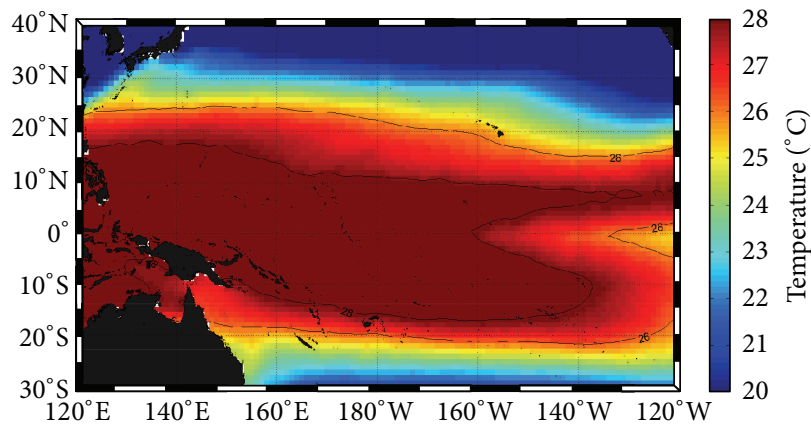

(c)



(b)

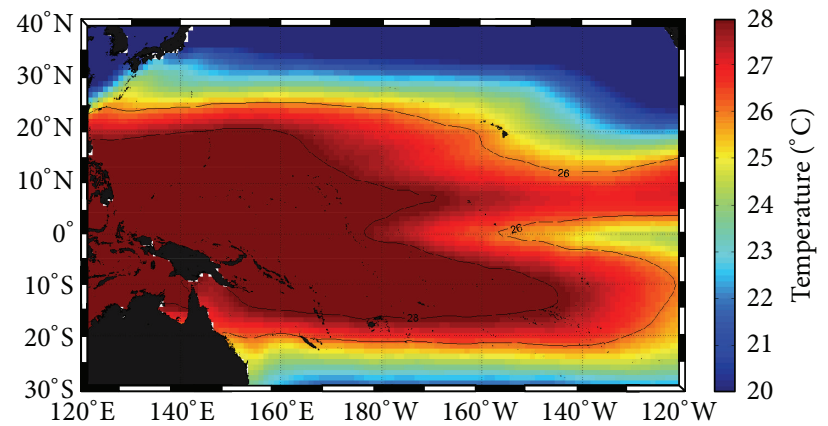

(d)

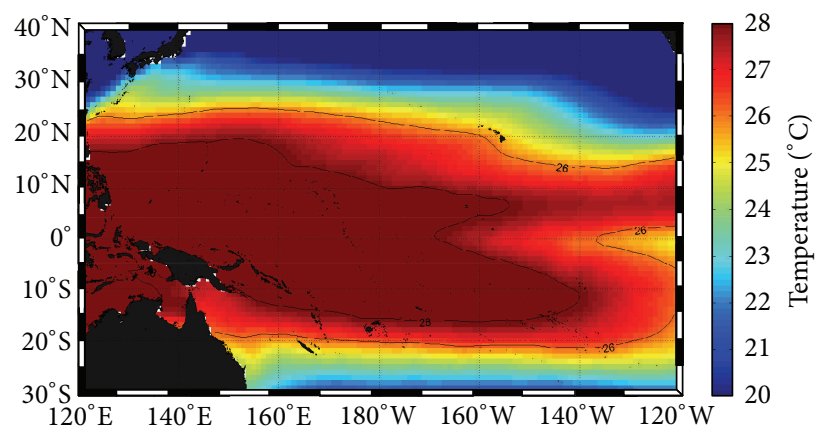

(e)

FIgURE 5: The distribution of average SST in (a) El Niño, (b) El Niño Modoki I, (c) El Niño Modoki II, (d) La Niña, and (e) normal years.

that the most occurrence is in El Niño years and then followed by El Niño Modoki I years, El Niño Modoki II years, normal years, and La Niña years, respectively.

\subsection{Area and Centroid of Western Pacific Warm Pool. Figure 5} shows the distribution of average SST in El Niño, El Niño Modoki I, El Niño Modoki II, La Niña, and normal years. Compared to normal years, warm water moves from west to the eastern tropical Pacific in El Niño years, moves to the central tropical Pacific in El Niño Modoki years, and shrinks to the western tropical Pacific in La Niña years. Due to the effect of El Niño, El Niño Modoki, and La Niña events on the SST distribution, the WPWP area is also changed in different events. The average area of WPWP is $3.53 \times 10^{7} \mathrm{~km}^{2}$ in El Niño years, $3.43 \times 10^{7} \mathrm{~km}^{2}$ in El Niño Modoki I years, $3.35 \times 10^{7} \mathrm{~km}^{2}$ in El Niño Modoki II years, $3.14 \times 10^{7} \mathrm{~km}^{2}$ in normal years, and $3.16 \times 10^{7} \mathrm{~km}^{2}$ in La Niña years as shown in
Figure 6. Figure 7 reveals the average location of the centroid of WPWP in different events. It is at $0.6^{\circ} \mathrm{N}, 170.1^{\circ} \mathrm{E}$ in $\mathrm{El}$ Niño years, at $0.6^{\circ} \mathrm{N}, 168.3^{\circ} \mathrm{E}$ in El Niño Modoki I years, at $0.5^{\circ} \mathrm{N}, 169.4^{\circ} \mathrm{E}$ in El Niño Modoki II years, at $0.9^{\circ} \mathrm{N}, 164.1^{\circ} \mathrm{E}$ in normal years, and at $0.9^{\circ} \mathrm{N}, 162.3^{\circ} \mathrm{E}$ in La Niña years. A comparison between the location of the centroid of WPWP and the formation of typhoon in different events is displayed in Figure 8. The correlation coefficient between locations of WPWP centroid and typhoon formation is up to 0.95 . This implies that El Niño, El Niño Modoki, and La Niña events indeed affect the formation position of a typhoon.

\section{Conclusions}

This is a preliminary study on the impacts of El Niño, El Niño Modoki, and La Niña events on the typhoon activity. We identify 19 El Niño events and 21 La Niña events during the period 


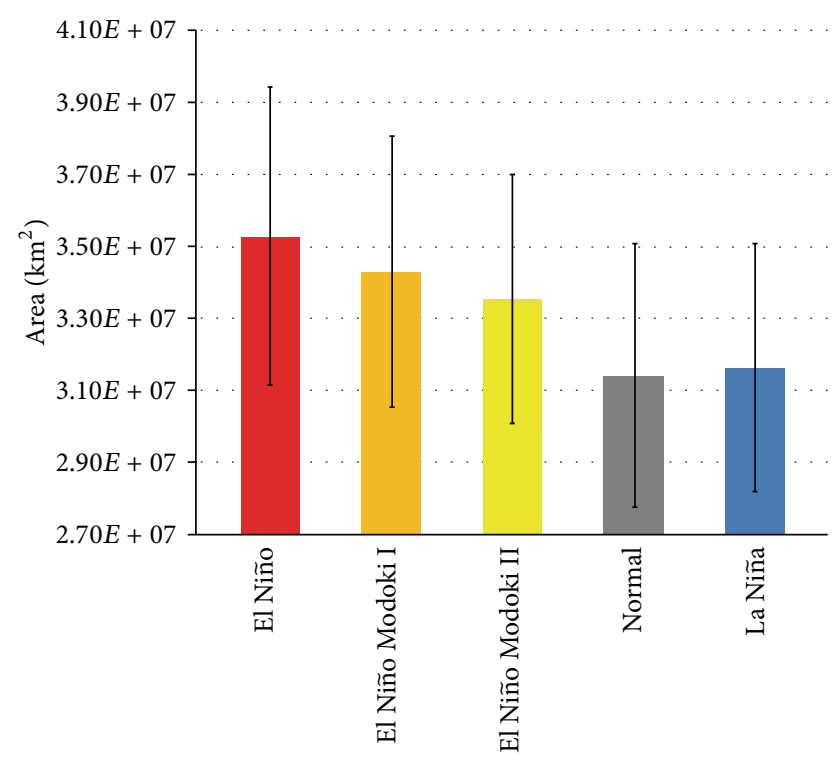

FIGURE 6: The average WPWP area in the five events. The bar represents one standard deviation.

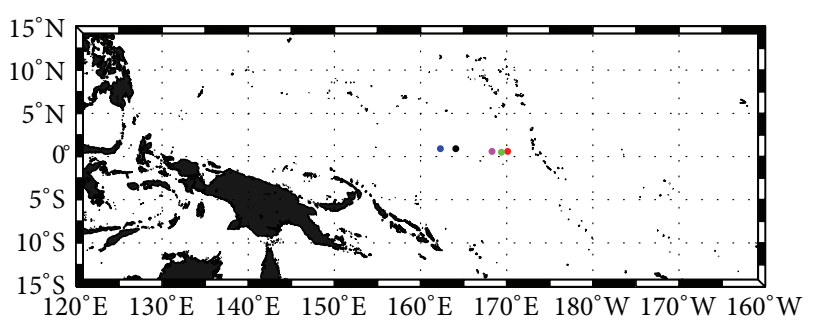

FIGURE 7: The average location of the centroid of WPWP in different events. El Niño (Red), El Niño Modoki I (Magenta), El Niño Modoki II (Green), La Niña (Blue), and the normal (Black), respectively.

of 1950-2012. We also find that there are two types of El Niño Modoki, I and II. The statistical results show that the lifetime, length of movement, and range of movement of typhoons are larger in El Niño years than those in La Niña years. The intensity in El Niño years is relatively strong, but the moving speed is almost the same as that in La Niña years. The average intensity of typhoon in El Niño Modoki I years is stronger than that in El Niño Modoki II years. The formation positions of typhoon are moved further eastward in El Niño years than that in La Niña years and much further eastward in El Niño Modoki years. ACE and ONI is corrected with a correlation coefficient of 0.79. The WPWP area is larger in El Niño and El Niño Modoki years than that in La Niña years. The centroid of the WPWP and the position of the typhoon formation are highly correlated with a correlation coefficient of 0.95 .

\section{Acknowledgments}

The authors appreciate the Met Office Hadley Centre for Climate Change for providing the HadISST data, as well as the Japan Meteorological Agency and the Joint Typhoon Warning Center for providing typhoon data. Two anonymous

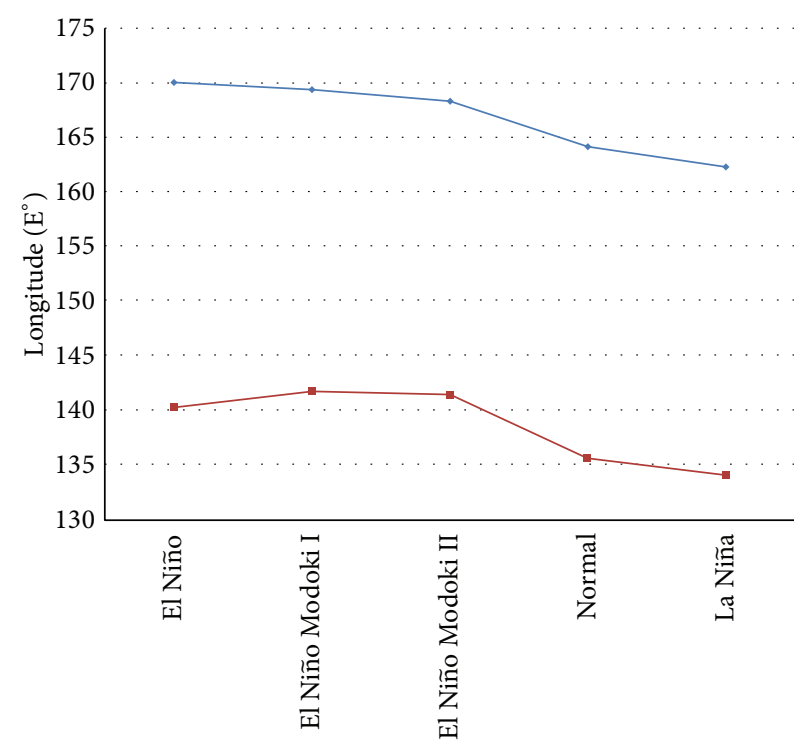

FIGURE 8: The centroid of WPWP (Blue) and the formation position of typhoon (Red) in five events.

reviewers providing useful comments and suggestions are also grateful. This work was supported by the National Science Council of Taiwan through Grants NSC 98-2611-M019-017-MY3 and NSC 102-2611-M-019-011.

\section{References}

[1] K. Ashok, S. K. Behera, S. A. Rao, H. Y. Weng, and T. Yamagata, "El Niño Modoki and its possible teleconnection," Journal of Geophysical Research C, vol. 112, no. 11, Article ID C11007, 2007.

[2] K. Ashok and T. Yamagata, "Climate change: the El Niño with a difference," Nature, vol. 461, no. 7263, pp. 481-484, 2009.

[3] J. S. Kug, F. F. Jin, and S. I. An, “Two types of El Niño events: cold tongue El Niño and warm pool El Niño," Journal of Climate, vol. 22, no. 6, pp. 1499-1514, 2009.

[4] J. V. Ratnam, S. K. Behera, Y. Masumoto, K. Takahashi, and T. Yamagata, "Anomalous climatic conditions associated with the El Niño Modoki during boreal winter of 2009," Climate Dynamics, vol. 39, no. 1-2, pp. 227-238, 2012.

[5] I. Zubiaurre and N. Calvo, "The El Niño-Southern Oscillation (ENSO) Modoki signal in the stratosphere," Journal of Geophysical Research D, vol. 117, no. 4, pp. 4722-4727, 2012.

[6] S. W. Yeh, J. S. Kug, B. Dewitte, M. H. Kwon, B. P. Kirtman, and F. F. Jin, "El Niño in a changing climate," Nature, vol. 461, pp. 515-515, 2009.

[7] H. Lopez and B. P. Kirtman, "Westerly wind bursts and the diversity of ENSO in CCSM3 and CSM4," Geophysical Research Letters, vol. 40, no. 17, pp. 4722-4727, 2013.

[8] J.-Y. Yu and H.-Y. Kao, "Decadal changes of ENSO persistence barrier in SST and ocean heat content indices: 1958-2001," Journal of Geophysical Research D, vol. 112, no. 13, Article ID D13106, 2007.

[9] H.-Y. Kao and J.-Y. Yu, "Contrasting eastern-Pacific and centralPacific types of ENSO," Journal of Climate, vol. 22, no. 3, pp. 615632, 2009. 
[10] H.-M. Kim, P. J. Webster, and J. A. Curry, "Impact of shifting patterns of Pacific Ocean warming on North Atlantic tropical cyclones," Science, vol. 325, no. 5936, pp. 77-80, 2009.

[11] G. H. Chen and R. H. Huang, "Influence of monsoon over the warm pool on interannual variation on tropical cyclone activity over the western North Pacific," Advances in Atmospheric Sciences, vol. 25, no. 2, pp. 319-328, 2008.

[12] X.-H. Yan, C.-R. Ho, Q. Zheng, and V. Klemas, "Temperature and size variabilities of the western Pacific warm pool," Science, vol. 258, no. 5088, pp. 1643-1645, 1992.

[13] X.-H. Yan, Y. He, W. T. Liu, Q. Zheng, and C.-R. Ho, “Centroid motion of the Western Pacific warm pool during three recent El Niño-Southern Oscillation events," Journal of Physical Oceanography, vol. 27, no. 5, pp. 837-845, 1997.

[14] S. Cravatte, T. Delcroix, D. X. Zhang, M. Mcphaden, and J. Leloup, "Observed freshening and warming of the western Pacific Warm Pool," Climate Dynamics, vol. 33, no. 4, pp. 565589, 2009.

[15] C.-Y. Lin, C.-R. Ho, Q. Zheng, S.-J. Huang, and N.-J. Kuo, "Variability of sea surface temperature and warm pool area in the South China Sea and its relationship to the western Pacific warm pool," Journal of Oceanography, vol. 67, no. 6, pp. 719-724, 2011.

[16] H.-M. Kim, P. J. Webster, and J. A. Curry, "Modulation of North Pacific tropical cyclone activity by three phases of ENSO," Journal of Climate, vol. 24, no. 6, pp. 1839-1849, 2011.

[17] C. Z. Wang, C. X. Li, M. Mu, and W. S. Duan, "Seasonal modulations of different impacts of two types of ENSO events on tropical cyclone activity in the western North Pacific," Climate Dynamics, vol. 40, no. 11-12, pp. 2887-2902, 2013.

[18] C. Wang and X. Wang, "Classifying El Niño Modoki I and II by different impacts on rainfall in Southern China and typhoon tracks," Journal of Climate, vol. 26, no. 4, pp. 1322-1338, 2013.

[19] D. P. Chambers, B. D. Tapley, and R. H. Stewart, "Longperiod ocean heat storage rates and basin-scale heat fluxes from TOPEX," Journal of Geophysical Research, vol. 102, no. 5, pp. 10525-10533, 1997.

[20] C.-R. Ho, X.-H. Yan, and Q. Zheng, "Satellite-observations of upper-layer variabilities in the western Pacific warm pool," Bulletin of the American Meteorological Society, vol. 76, no. 5, pp. 669-679, 1995.

[21] G. D. Bell, M. S. Halpert, R. C. Schnell et al., "Climate assessment for 1999," Bulletin of the American Meteorological Society, vol. 81, no. 6, pp. S1-S50, 2000.

[22] H. M. Kim, M. I. Lee, P. J. Webster, D. Kim, and J. H. Yoo, “A physical basis for the probabilistic prediction of the accumulated tropical cyclone kinetic energy in the western North Pacific," Journal of Climate, vol. 26, no. 20, pp. 7981-7991, 2013.

[23] G. Skok, J. Bacmeister, and J. Tribbia, "Analysis of tropical cyclone precipitation using an object-based algorithm," Journal of Climate, vol. 26, no. 8, pp. 2563-2579, 2013.

[24] T. E. Larow, L. Stefanova, D. W. Shin, and S. Cocke, "Seasonal Atlantic tropical cyclone hindcasting/forecasting using two sea surface temperature datasets," Geophysical Research Letters, vol. 37, no. 2, Article ID L02804, 2010.

[25] R. N. Maue, "Recent historically low global tropical cyclone activity," Geophysical Research Letters, vol. 38, no. 14, Article ID L14803, 2011.

[26] S. S. Chand and K. J. E. Walsh, "Modeling seasonal tropical cyclone activity in the Fiji region as a binary classification problem," Journal of Climate, vol. 25, no. 14, pp. 5057-5071, 2012.
[27] P. K. Pradhan, B. Preethi, K. Ashok, R. Krishnan, and A. K. Sahai, "Modoki, Indian Ocean dipole, and western North Pacific typhoons: possible implications for extreme events," Journal of Geophysical Research D, vol. 116, no. 18, Article ID D18108, 2011.

[28] G. Chen and C. Y. Tam, "Different impacts of two kinds of Pacific Ocean warming on tropical cyclone frequency over the western North Pacific," Geophysical Research Letters, vol. 37, no. 1, Article ID L01803, 2010. 

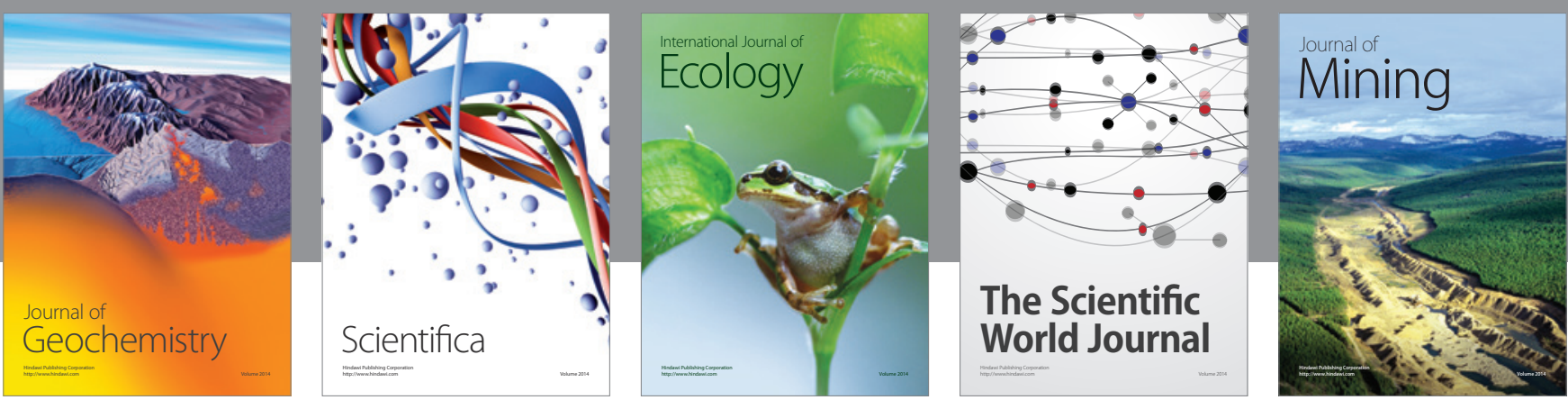

The Scientific World Journal
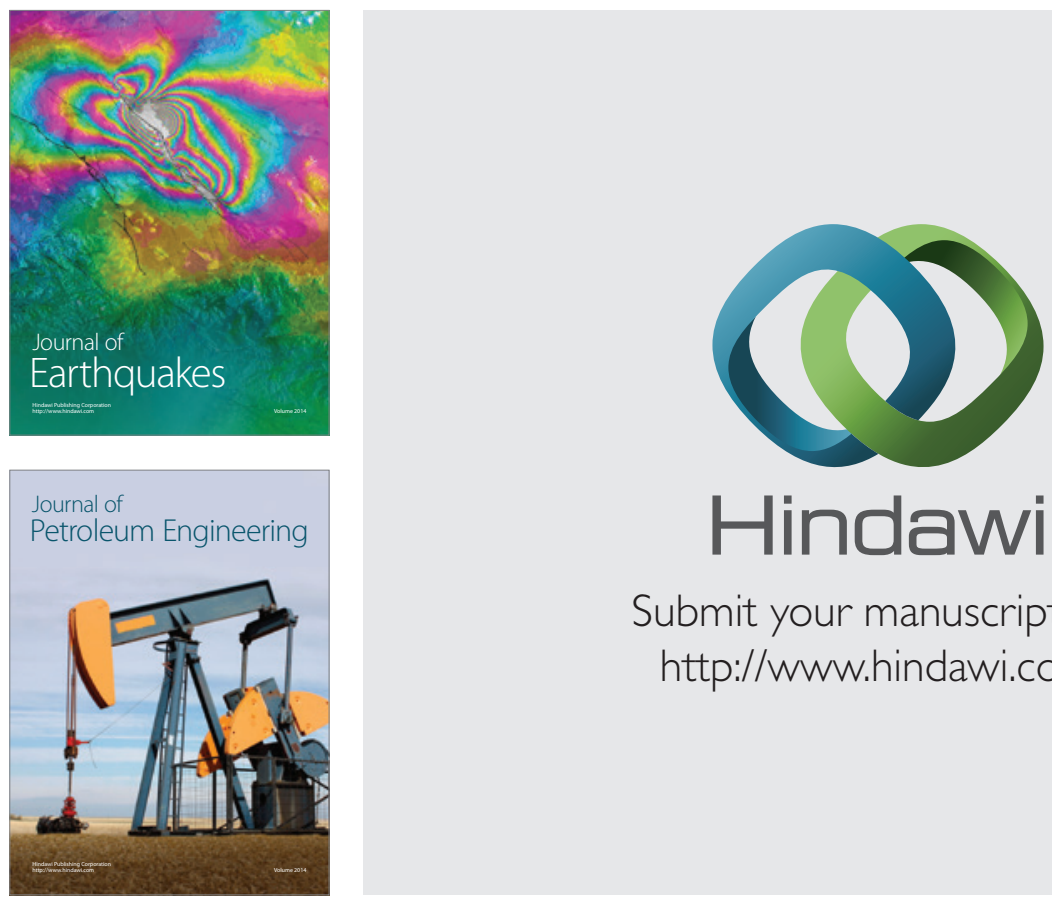

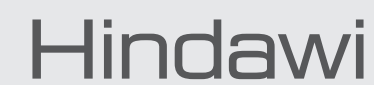

Submit your manuscripts at

http://www.hindawi.com
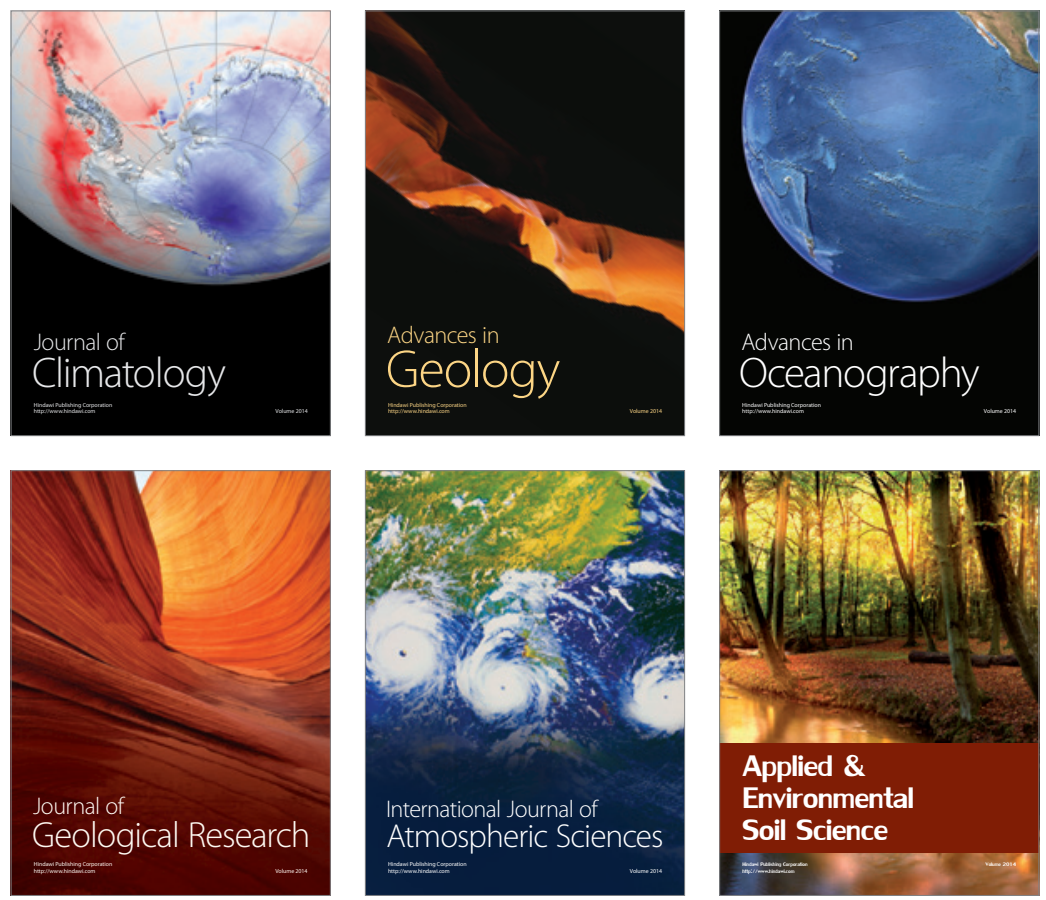
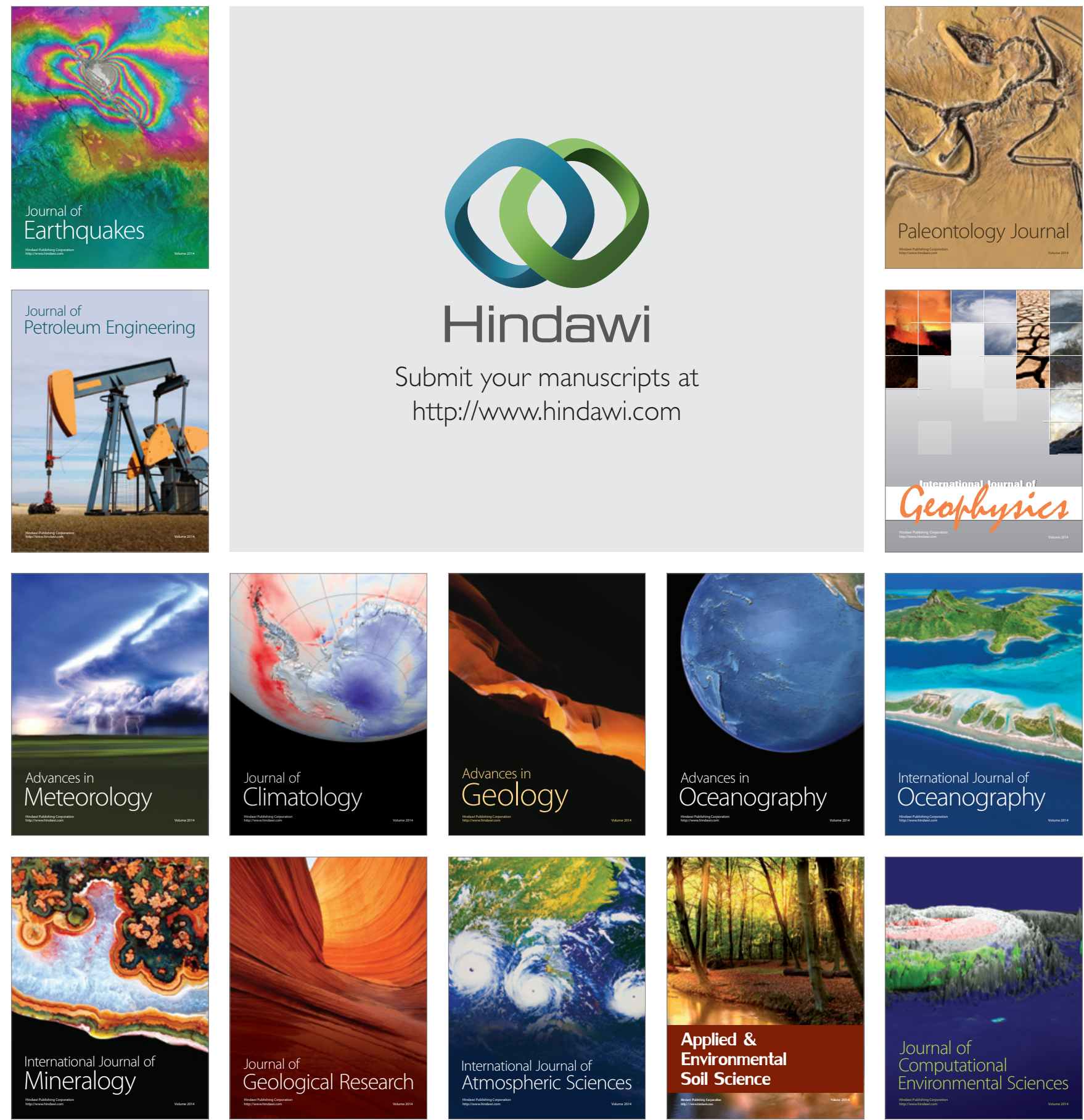